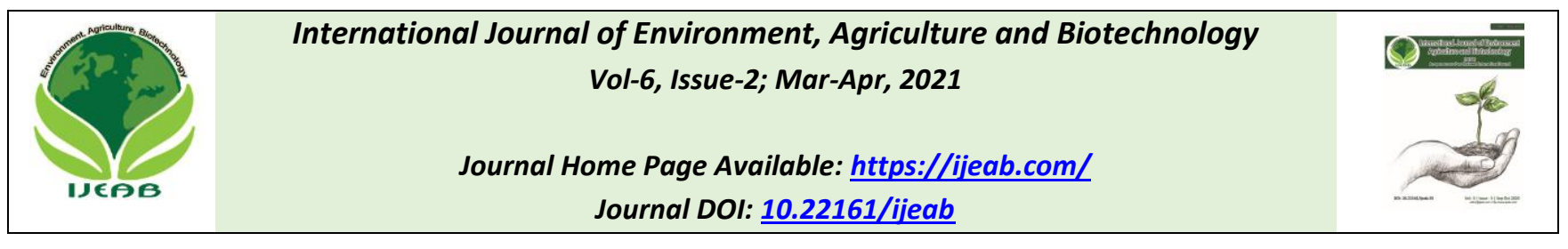

\title{
Gender Involvement in Crop Production and Livestock Related Activities in Chitwan and Lamjung District of Nepal
}

\author{
B. P. Mishra, B. Osti
}

Agriculture and Forestry University, Chitwan, Nepal

Received: 03 Jan 2021; Received in revised form: 21 Feb 2021; Accepted: 21 Mar 2021; Available online: 16 Apr 2021

(C)2021 The Author(s). Published by Infogain Publication. This is an open access article under the CC BY license

(https://creativecommons.org/licenses/by/4.0/).

\begin{abstract}
A study was carried out during 2019 with the aim to assess gender involvement in crop production and livestock sector. Two hundred and forty (240) smallholder farmers were selected randomly, 120 smallholder farmers each from Chitwan and Lamjung district of Nepal. Findings revealed that the gender involvement in most of the activities on crop production and livestock is dominated by joint participation of both male and female. However, in terms of technology adoption and control over land resources, status of female participation was quite low compared to male. Thus it is recommended to bring equal involvement of both male and female in all aspects of production and resources control.
\end{abstract}

Keywords-Gender involvement, smallholder farmers, crop production, livestock.

\section{INTRODUCTION}

Nepal being an Agrarian country, agriculture production accounts for around $24.26 \%$ of total GDP and about threequarters of the population work in agriculture sector of Nepal (MoAD, 2019). Socially constructed relationship between men and women in a society is referred as 'Gender' (Eagly , 1987). Gender role refers to how men and women should think, act and feel according to the existing norms and traditions in our society (Groverman and Gurung , 2001). Gender roles are highly influenced by the interactions between individuals and their social, historical and economic environments (West and Zimmerman , 1987). Strong relationship exists between gender and agricultural activities in the Nepalese household (Bajracharya, 1994; Devkota and Pyakuryal, 2006). Gender roles are dynamic and changing as per the societal change (Devkota, 2010). This study aims to assess gender involvement in crop production and livestock sector at the household of Chitwan and Lamjung district.

\section{METHODOLOGY}

The study was carried out in Chitwan and Lamjung district of Nepal during 2019. Smallholders constitute more than
$50 \%$ of Nepalese farmers, cultivating less than 0.5 ha per household (CBS, 2011). Hence, to get the knowledge of the dominant workforce, all smallholder farmers constituted the population of the study. One hundred and twenty (120) farmers were selected randomly from each district. Information was largely collected through FGD, KII and face to face interview schedule conducted using pre-tested questionnaire with household head. Frequency was used to interpret the findings of the study.

\section{RESULTS}

\subsection{Basic information of the respondents}

Gender, age, education, ethnicity, occupation, farming experience, number of male and female per household of the respondents were measured and categorized (Table 1). Out of 240 households surveyed, findings revealed that majority of the respondents were male. Similarly, majority of the respondents were of economically active age group. Half of the respondents had intermediate and higher degree of education. Majority of the respondents were Brahmin/Chhetri. More than half of the respondents were dependent only on agriculture as source of income. Majority of the respondents had greater than 30 years of 
farming experience. Number of males per household was higher compared to number of number of female in range of 5-10 size.

Table 1. Basic information of the respondents across the study districts

\begin{tabular}{ll}
\hline Basic information & Frequency \\
\hline Gender of household head & \\
Male & $164(68.33)$ \\
Female & $76(31.67)$ \\
Age of household head & \\
(years) & \\
Economically active(15-59) & $164(68.33)$ \\
Dependent(<14 and >60) & $76(31.67)$ \\
Education & \\
Illiterate & $30(12.5)$ \\
Lower level & $16(6.67)$ \\
Secondary level & $70(29.17)$ \\
Intermediate & $84(35)$ \\
Bachelor & $40(16.66)$ \\
Ethnicity & $136(56.67)$ \\
Brahmin/Chhetri & $104(43.33)$ \\
Janajati & $60(25)$ \\
Dalit & $4(1.67)$ \\
Occupation & \\
Agriculture & \\
Agriculture + off farm & \\
Farming experience (years) & \\
1 - 15 & \\
\hline & \\
\hline
\end{tabular}

\begin{tabular}{llll}
\hline 30 & & $164(68.34)$ \\
$\begin{array}{l}\text { Number of } \\
\text { household }\end{array}$ & & \\
$1-4$ & & $108(45)$ \\
$5-10$ & & $132(55)$ \\
Number of female per & \\
household & & & $125(52.08)$ \\
$1-4$ & & $115(47.92)$ \\
$5-10$ & & &
\end{tabular}

Source: Field Survey, 2019.

Note: Figures in parentheses indicate percentage

\subsection{Gender involvement in crop production related activities}

Both men and women were involved in the activities related to crop production (Table 2). However, the degree, level, and stage of gender participation in various activities related to the crop productionvaried from one to other. Some of the activities were predominantly done by male, some by female and some of them were done by both male and female. In agricultural activities such as buying of seeds, land preparation, planting and sowing, there was major involvement of both the gender, which was $55.83 \%$, $52.5 \%, 50 \%$ and $50 \%$ respectively. In contrast to that, activities such as tilling and weeding were dominantly handled by female member. There was involvement of only $15 \%$ male in postharvest operation which was very low as compared to female involvement (42.5\%). However, financial and decision making activities such as selling of land, leasing of land and adoption of technology were mainly handled by male member of the household which includes $68.33 \%, 68.33 \%$ and $65.83 \%$ male involvement respectively.

Table 2. Gender involvement in crop production related activities across the study districts

\begin{tabular}{llll}
\hline Activities & \multicolumn{2}{l}{ Gender involvement in crop production related activities $(\mathrm{n}=240)$} \\
\cline { 2 - 4 } & Male & Female & Both \\
\hline Buying of seeds & $36(15)$ & $70(29.17)$ & $134(55.83)$ \\
Land preparation & $74(30.83)$ & $40(16.67)$ & $126(52.5)$ \\
Planting & $54(22.5)$ & $66(27.5)$ & $120(50)$ \\
Sowing & $54(22.5)$ & $66(27.5)$ & $120(50)$ \\
Tilling & $52(21.67)$ & $102(42.5)$ & $86(35.83)$ \\
Weeding & $52(21.67)$ & $102(42.5)$ & $86(35.83)$ \\
Harvesting & $38(15.83)$ & $60(25)$ & $142(59.17)$ \\
Postharvest operations & $36(15)$ & $102(42.5)$ & $102(42.5)$ \\
\hline
\end{tabular}




\begin{tabular}{llll}
\hline Selling of produce & $80(33.33)$ & $70(29.17)$ & $90(37.5)$ \\
Selling of land & $164(68.33)$ & $30(12.5)$ & $46(19.17)$ \\
Leasing of land & $164(68.33)$ & $30(12.5)$ & $46(19.17)$ \\
Adoption of technology & $158(65.83)$ & $42(17.5)$ & $40(16.67)$ \\
\hline
\end{tabular}

Source: Field Survey, 2019

Note: Figures in parentheses indicate percentage respondents' responses

\subsection{Gender involvement in livestock related activities}

In contrast to the crop production, there was found to be higher involvement of both the gender in most of the livestock related activities (Table 3). Activities such as fodder collection, watering to the animals and overall management were carried by women in greater extent compared to the male, however, there was no such significant difference in frequencies. Male participation was found to be higher in decision making activities such as adoption of technology. Only $16.67 \%$ female own full decision making power for technology adoption whereas $63.33 \%$ male hold full power in decision making. Activities such as milking of animals and grazing were also dominated equally by both the genders which accounts for $45.84 \%$ and $44.17 \%$ frequency respectively.

Table 3. Gender involvement in livestock related activities across the study districts

\begin{tabular}{|c|c|c|c|}
\hline \multirow[t]{2}{*}{ Activities } & \multicolumn{3}{|c|}{ Gender involvement in livestock related activities $(n=240)$} \\
\hline & Male & Female & Both \\
\hline $\begin{array}{l}\text { Feed preparation to } \\
\text { the animals }\end{array}$ & $48(20)$ & $74(30.83)$ & $118(49.17)$ \\
\hline Fodder collection & $46(19.17)$ & $70(29.17)$ & $124(51.66)$ \\
\hline $\begin{array}{l}\text { Watering to the } \\
\text { animals }\end{array}$ & $34(14.17)$ & $70(29.17)$ & $136(56.66)$ \\
\hline $\begin{array}{l}\text { Overall care and } \\
\text { management of } \\
\text { livestock }\end{array}$ & $44(18.33)$ & $50(20.83)$ & $146(60.84)$ \\
\hline Milking animals & $74(30.83)$ & $56(23.33)$ & $110(45.84)$ \\
\hline Grazing animals & $74(30.83)$ & $60(25)$ & $106(44.17)$ \\
\hline $\begin{array}{l}\text { Decision to sell } \\
\text { animals }\end{array}$ & $70(29.16)$ & $40(16.67)$ & $130(54.17)$ \\
\hline $\begin{array}{l}\text { Adoption } \\
\text { technology }\end{array}$ & $152(63.33)$ & $40(16.67)$ & $48(20)$ \\
\hline
\end{tabular}

Source: Field Survey, 2019

Note: Figures in parentheses indicate percentage respondents' responses

\section{DISCUSSION}

There was found to be varied involvement of male and female in different activities related to crop production. Greater time and effort demanding task such as land preparation, sowing and harvesting were done by involvement of both the gender. Zewdu et al. (2016) reported that males were found to be more involved in ploughing and harvesting of horticultural crop. But this was found quite different in our study. Although tillage is considered to be extremely laborious job, it was performed by involvement of women to greater extent. Olowa and
Olowa (2015) found that women are more involved in weeding, watering, transplanting and harvesting. Similarly, there was greater involvement of women in activities such as weeding, harvesting and post-harvest operation. There was greater involvement of male in adoption and decision making task such as selling of land, leasing of land and technology adoption. Result is in line with Agarwal (2015) who reported lack of ownership and access to land for women. FAO (2010) reported female have no access to and decision-making role on technology use. Ogato et al. (2009) reported man as the principal decision maker in 
family being household head. Zewdu et al. (2016) also revealed that men are the heads of households and are the principal decision- makers in most of the household however it might involve some consultation with women. The patriarchal system is seen to be accelerating factor for domination of male over female. In case of livestock related activities, there was greater involvement of both the gender. Feed preparation, fodder collection, watering and other management related activities of livestock was performed jointly regardless of gender whereas male involvement was found to be higher in technology adoption related decision. But in case of selling of produce and animals, involvements were made jointly.

\section{CONCLUSION}

Findings of this study revealed that gender involvement in most of the activities on crop production and livestock is not single domination of either male or female, but towards joint participation of both. However, access of female in terms of technology adoption and control over land resources were quite low compared to male. Thus, it is suggested that, implementing program and policies which would bring equal involvement of both male and female in all aspects of production and resources control will be helpful.

\section{REFERENCES}

[1] Agarwal, B. (2015). Food Security, Productivity, and Gender Inequality (Chapter 11). In The Oxford Handbook of Food, Politics and Society. Oxford University Press.

[2] Bajracharya, B. (1994). Gender issues in Nepali agriculture: A review. Winrock Research Report Series, No. 25. Kathmandu: HMG, Ministry of Agriculture/ Winrock International.

[3] Central Bureau of Statistics (CBS). (2011). Nepal Living Standard Survey 2010/11. Statistical Report, Volume II. Central Bureau of Statistics, National Planning Commission Secretariat. November, 2011. Government of Nepal. National Planning Commission Secretariat. November 2012.

[4] Devkota, D. and Pyakuryal, K. N. (2006). Changing gender roles and Nepalese agriculture system. Proceedings of the SASON, 2006.

[5] Devkota, D. (2010). Changing Gender Roles in Nepalese Rural Society. Unpublished PhD Dissertation, pp 321.

[6] Eagly, A. H. (1987). Sex Differences in Social Behaviour: A Social Role Interpretation. Hillsdale, NS: Erlbaum.

[7] FAO. (2010). Integration of Gender in Agriculture: An Analysis of Situation. Pulchowk, Nepal: Food and Agriculture Organization of the United Nations.

[8] Groverman and Gurung, J. (2001). Gender and Organizational Change: Training Manual, ICIMOD, Kathmandu, Nepal.
[9] MoAD.(2019). Stastistical year Book, Kathmandu: Ministry of Agricuture Development.

[10] Ogato, G. S., Boon, E. K., and Subramani, J. (2009). Gender roles in crop production and management practices: A case study of three rural communities in Ambo District, Ethiopia. Journal of human ecology, 27(1), 1-20.

[11] Olowa, O. A., and Olowa, O. W. (2015). Gender Issues of Labour Participation in Vegetable Production in Ikorodu Local Government Area of Lagos State. Current Research in Agricultural Sciences, 2(4), 114-122.

[12] West, C., and Zimmerman, D. H. (1987). Doing gender. Gender \& society, 1(2), 125-151.

[13] Zewdu, A., Zenebe, G., Abraha, B., Abadi, T., and Gidey, N. (2016). Assessment of the Gender Role in Agricultural Activities at Damota Kebele of Haramaya District, Eastern Hararghe Zone, Ethiopia. Assessment, 26. 